\title{
PERSEPSI MASYARAKAT TERHADAP APLIKASI TIKTOK SEBAGAI MEDIA MENURUNKAN TINGKAT STRES DI ERA PANDEMI COVID-19
}

\author{
Kadek Ari Setia Utama Putra ${ }^{1}$ Gede Wisnu Permana ${ }^{2}$ Putu Yuna Sephiani ${ }^{3}$ Ni Komang Sutriyanti ${ }^{4}$ \\ SMA Negeri Bali Mandara123 \\ Universitas Hindu Negeri I Gusti Bagus Sugriwa Denpasar4
}

\begin{abstract}
Social media is a medium for socializing and communicating with each other and is done online which is not regulated by space and time. Social media can be used as a medium to communicate privately and even in groups, share files, videos, music, and so on. Social media which is busy being used to reduce stress in the current pandemic era, one of which is the TikTok application. TikTok is a social media and music video platform from China. This application was first released in September 2016. The purpose of this research is to see the perception of the TikTok application as a medium to reduce stress levels in the Covid-19 pandemic era. Method of collecting data used included interviews, questionnaire questionnaires, documentation, and observation. The data obtained were analyzed using a qualitative descriptive method. The research results are as follows 64\% of people say TikTok is a medium for reducing stress. The public accepts and rejects TikTok as the right medium to reduce stress in the Covid-19 pandemic era for various reasons given. From these results it can be ignored that the TikTok application influences TikTok users, both positive and negative. This has led to various responses from the public regarding the TikTok application.
\end{abstract}

Keywords TikTok, Covid-19, Stress, Community Response.

\section{PENDAHULUAN}

Wabah dapat dikatakan sama dengan pandemi, yaitu berjangkitnya suatu penyakit menular dalam masyarakat yang jumlah penderitanya meningkat secara nyata melebihi keadaan yang lazim pada waktu dan daerah tertentu serta dapat menimbulkan malapetaka (UU 4/1984). Hingga pada saat ini

\footnotetext{
1 arisetiautama1401@gmail.com

2 wisnupramana17@gmail.com

3 yunasephiani1303@gmail.com

${ }^{4}$ nikomangsutriyanti@gmail.com
} 
kehadiran suatu wabah yang mendunia, wabah ini berupa virus yang menyerang ratusan hingga ribuan jiwa di dunia. Severe acute respiratory syndrome coronavirus 2 (SARS-CoV-2) yang lebih dikenal dengan nama virus Corona adalah jenis baru dari corona virus yang menular ke manusia. Infeksi virus Corona disebut Covid-19 (Corona Virus Disease 2019) dan pertama kali ditemukan di Kota Wuhan, China pada akhir Desember 2019. Virus ini menular dengan sangat cepat dan telah menyebar ke hampir semua negara, termasuk Indonesia (Kompas.com, 2020).

Pandemi virus Corona di Indonesia memberikan dampak pada gaya hidup, akibat berbagai kebijakan yang berlaku untuk penanganan Covid-19. Kini masyarakat lebih mengandalkan teknologi digital untuk tetap dapat menjalani kehidupan sosial di tengah kebijakan physical distancing dan PSBB (Pembatasan Sosial Berskala Besar). Banyak responden merasa kehidupan sosialnya terganggu karena tidak bisa berkumpul bersama keluarga dan teman, karena harus menjaga jarak (physical distancing) dan mengikuti anjuran untuk di rumah saja (Aufar, 2020: 158). Tidak hanya gaya hidup, Covid-19 memberikan dampak pada ekonomi masyarakat. Berdasarkan data Kementerian Ketenagakerjaan, sebanyak 10,6\% diantaranya atau sekitar 160 ribu orang kehilangan pekerjaan karena PHK, sedangkan $89,4 \%$ lainnya karena di rumahkan (Tobing, 2020). Covid-19 yang disebabkan oleh virus Corona membuat beberapa masyarakat khawatir, karena pemberitaan di media yang rentan meningkatkan kondisi psikologis yang buruk. Dari sana pula (dalam Muslim, 2020: 192), para orang dewasa juga mengalami kekhawatiran karena takut di PHK
(Pemutusan Hubungan Kerja) yang tentunya menyebabkan stres.

Ketakutan dan kecemasan tentang suatu penyakit, dapat menyebabkan emosi yang kuat pada orang dewasa dan anak-anak. Pandemi ini membuat banyak orang merasa bingung, cemas, stres, dan frustasi (Kompas.com, 2020). Dengan program pemerintah seperti ini, nyatanya manfaat yang diterima masyarakat kurang efektif. Bantuan pemerintah yang diperuntukkan untuk masyarakat nyatanya belum tepat sasaran. Akibat dari kurang efektifnya program pemerintah tersebut, masyarakat Indonesia merasakan beban yang cukup berat dan menjadi stres. Sehingga masyarakat Indonesia memerlukan alternatif untuk menurunkan tingkat stres yang dialaminya. Alternatif yang menjadi pilihan masyarakat untuk menghilangkan stres adalah TikTok.

TikTok adalah salah satu platform media sosial yang perkembangannya paling cepat di dunia. TikTok memungkinkan penggunanya untuk membuat video pendek berdurasi 15 detik disertai musik, filter, dan beberapa fitur kreatif lainnya. Saat ini aplikasi TikTok sangat digemari masyarakat Indonesia baik dari kalangan remaja, anak-anak, sampai orang tua (Adawiyah, 2020: 136). Masyarakat Indonesia menggunakan TikTok untuk menghilangkan rasa stres di era pandemi Covid-19, yang mewajibkan mereka untuk tetap diam di rumah. Namun, aplikasi TikTok dapat menurunkan tingkat stres masyarakat di era pandemi Covid-19, belum pasti diketahui kebenarannya. Dari permasalahan tersebut, peneliti tertarik untuk mengkaji, "Pengaruh Aplikasi TikTok sebagai Media Menurunkan Tingkat Stres di Era Pandemi Covid-19" 
Peneliti dapat mengidentifikasi beberapa permasalahan yang disebabkan ramainya penggunaan aplikasi TikTok di era pandemi Covid-19 yaitu; ramainya penggunaan aplikasi TikTok di era pandemi Covid-19 diakibatkan oleh masyarakat yang merasa bosan karena menjalani isolasi mandiri. Rasa stres dipicu oleh tekanan ekonomi, kehidupan sosial, dan kesehatan mental di era pandemi Covid-19. Adanya kecendrungan masyarakat Indonesia ketergantungan terhadap aplikasi TikTok Adanya berbagai respons dari masyarakat Indonesia terhadap aplikasi TikTok, baik respons positif maupun negatif.

Berdasarkan identifikasi masalah, adapun rumusan masalah dari penelitian ini adalah mengenai respons masyarakat terkait aplikasi TikTok sebagai media penurun tingkat stres di era pandemi, dan pengaruh positif dan negatif aplikasi TikTok sebagai media menuruunkan tingkat stres di era pandemi Covid-19. Adapun tujuan dari penelitian ini adalah; untuk mengetahui respons masyarakat mengenai aplikasi TikTok sebagai media penurun stres di era pandemi Covid-19. Kemudian mengetahui pengaruh positif dan negatif aplikasi TikTok sebagai media menurunkan tingkat stres di era pandemi Covid-19.

Dengan adanya penelitian ini, peneliti mengharapkan penggunaan aplikasi TikTok dapat membawa pengaruh positif bagi pengguna. Aplikasi TikTok dapat menjadi media alternatif sebagai penurun tingkat stres di era pandemi Covid-19. Penelitian mengenai TikTok sebagai media penghilang stres masyarakat pada masa pandemi Covid19 ini belum pernah dikaji oleh penelitipeneliti yang terdahulu. Karena TikTok benarbenar ramai digunakan oleh masyarakat untuk menghilangkan stres khususnya pada saat pandemi Covid-19, hal ini membuat peneliti tertarik untuk mengkaji lebih dalam mengenai bagaimana pengaruh dan respons dari masyarakat mengenai aplikasi TikTok sebagai media penurun tingkat stres di era pandemi Covid-19.

\section{METODE}

Penelitian ini menggunakan perpaduan antara metode kualitatif dan kuantitatif, Metode pengumpulan data yang digunakan dalam penelitian ini adalah; wawancara dan angket kuesioner. Sedang teknik analisis data dalam penelitian ini adalah data yang diperoleh baik berupa kajian pustaka seperti buku, jurnal, laporan, maupun penelusuran data dan informasi melalui internet, dijadikan sebuah referensi dalam penyusunan penelitian. Data yang diperoleh melalui wawancara dan penyebaran angket kuesioner. Analisis ini dilakukan untuk mencari keterkaitan sesuai dengan data yang dikaji. Teknik analisis data ini menjabarkan dan menguraikan secara sistematis sehingga menjadi sebuah informasi yang berkaitan dengan objek penelitian yang dikaji mengenai respons masyarakat dan dampak positif dan negatif mengenai aplikasi TikTok sebagai media menurunkan tingkat stres di era pandemi ini.

\section{PEMBAHASAN}

Persepsi Masyarakat mengenai Aplikasi TikTok sebagai Media Menurunkan Tingkat Stres di Era Pandemi Covid-19

Di tengah pandemi ini, banyak pengguna media sosial yang membuat video TikTok sebagai hiburan dan sarana untuk menyalurkan kreatifitas mereka agar tidak merasa bosan dan stres ketika diam di rumah. Banyak masyarakat menyukai dan menerima aplikasi TikTok yang saat ini tengah ramai 
digunakan. Masyarakat merasa senang menggunakan TikTok karena dapat menemukan berbagai macam konten. Aplikasi TikTok ramai digunakan karena cara penggunaannya yang mudah serta menyediakan tempat bagi orang-orang yang suka membuat video namun belum bisa mengoperasikan aplikasi editor video dengan menyediakan berbagai filter, musik dan efek (Susilowati, 2018: 177). Selain itu masyarakat dapat menemukan berbagai informasi informasi yang tengah hangat diperbincangkan.

Ada juga masyarakat yang menolak kehadiran TikTok ditengah masyarakat. Hal itu dikarenakan ada sebagian juga yang membuat video yang kurang mendidik dan tidak bermanfaat seperti video seseorang yang sedang marah-marah dan curhat, serta video yang lebih condong menampilkan aurat tubuh ketika bergoyang (Aprilian dkk., 2019: 221) bahkan ditampilkan oleh anak sekolahan yang memakai seragam sekolah. Video seperti itu dan tidak pantas dipertontonkan. Membuat video yang tidak sewajarnya, bahkan tidak hanya remaja saja, mereka melibatkan anak-anak kecil dalam pembuatan video TikTok demi respons yang banyak dari netizen. Banyak masyarakat mengatakan alasan TikTok sebagai media hiburan, maka masih banyak media lain seperti YouTube, Instagram, dan media lainnya.

Berdasarkan data dari hasil kuesioner mengenai aplikasi TikTok adalah media paling menghibur di era pandemi Covid-19 dengan persentase $76 \%$. Hal ini dikarenakan aplikasi TikTok adalah media yang dapat menghibur masyarakat di era pandemi saat ini. Kita bisa menemukan berbagai video menarik di dalamnya seperti video lucu, video tutorial memasak, video informasi terkini, dan masih banyak lagi. Pernyataan setelah bermain TikTok rasa stres, lelah, dan bosan akan hilang setelah bermain TikTok belum bisa diterima oleh masyarakat secara keseluruhan dibuktikan dengan persentase hanya menunjukkan 56\%. Artinya masih ada alternatif lain yang digunakan masyarakat untuk mengurangi rasa stres.

Pengguna TikTok merasa senang saat menggunakan aplikasi TikTok dengan persentase $62 \%$. Dengan persentase $64 \%$ masyarakat mengatakan bahwa aplikasi TikTok merupakan media yang dipilih untuk menurunkan tingkat stres dalam menghadapi situasi saat ini. Pengaruh aplikasi TikTok bagi masyarakat ada yang sifatnya positif dengan persentase $76 \%$ dan berpengaruh negatif bagi masyarakat dengan persentase $64 \%$.

Berdasarkan hasil wawancara dengan berbagai narasumber, yaitu Putu Nadi Asih (pelajar) dan Luh Canisning (mahasiswa) sebagai masyarakat yang aktif menggunakan aplikasi TikTok di era pandemi Covid-19. Di era pandemi saat ini, adanya himbauan dari pemerintah yang meminta masyarakat bekerja, sembahyang, dan belajar dari rumah. Sebagai pelajar, selain belajar dan mengerjakan tugas, mereka turut membantu orang tua mengerjakan pekerjaan rumah. Dalam situsi ini memicu timbulnya rasa bosan dan lelah, dengan tugas menumpuk dari sekolah membuat pikiran jenuh dan stres. Jika biasanya kita pergi bersama teman-teman untuk mengurangi rasa stres, misalnya jalan jalan ke pantai, restoran, bioskop, atau pun tempat lain, kini kita hanya bisa melakukan semua kegiatan dari rumah. Ingin keluar jalan-jalan untuk menghilangkan rasa bosan, namun takut terinfeksi virus Covid-19 masih begitu menakutkan bagi masyarakat. 
Melihat saat ini pesatnya perkembangan teknologi, masyarakat memanfaatkan hal tersebut untuk membantu mengurangi rasa stres dan bosan ketika berada di rumah. Saat ini banyak masyarakat memanfaatkan aplikasi TikTok sebagai media yang membantu menurunkan tingkat stres di era pandemi saat ini. Pada aplikasi TikTok terdapat berbagai video menarik pada aplikasi tersebut sehingga penikmat merasa terhibur. Aplikasi TikTok adalah suatu aplikasi yang mampu membantu dalam pembuatan konten berupa video dengan cara mengedit yang mudah. Membuat aplikasi ini lebih baik dari aplikasi editing lainnya. Selain mudah digunakan aplikasi TikTok merupakan suatu media yang mampu membantu orang-orang untuk menyalurkan bakat yang dimiliki.

Kemajuan teknologi saat ini jika tidak bisa dimanfaatkan dengan bijak, maka kita menjadi kecanduan, tentu akan sangat merugikan diri kita sendiri, orang tua, dan orang lain. Oleh karena itu, bermain TikTok tidak dijadikan prioritas agar tidak menjadi kecanduan. Sehingga para pengguna tidak terlalu fokus bermain TikTok dibandingkan dengan melakukan pekerjaan yang lebih produktif. Tidak bisa mengatur waktu dalam menggunakan aplikasi TikTok akan memberikan banyak pengaruh negatif bagi diri sendiri dan juga bagi orang lain.

\section{Pengaruh Positif dan Negatif Aplikasi Tiktok sebagai Media Menurunkan Tingkat Stres di Era Pandemi Covid-19}

Video-video yang ada pada aplikasi TikTok sangat beragam dan sebagian besar konten yang dibuat bermanfaat bagi masyarakat. Adapun pengaruh positif dari aplikasi TikTok yang digunakan sebagai media penurun tingkat stres di era pandemi Covid-
19 adalah, TikTok sebagai salah satu aplikasi yang dapat mendorong kreativitas seseorang dalam membuat suatu karya, membantu untuk mengekspresikan kreativitas khususnya dalam pembuatan video karena dapat membuat video dengan efek spesial dan unik dengan mudah. TikTok juga menyuguhkan berbagai macam musik untuk latar video (Hasilohan dkk., 2020: 75), sehingga penggunanya dapat menciptakan video yang lebih menarik.

Hal tersebut membuat para pengguna TikTok dapat membuat video unik dengan mudah dan menciptakan kontenkonten yang menarik sebagai hiburan, saluran edukasi mendidik dan saluran lain yang bersifat positif. Aplikasi TikTok membantu seseorang membuat berbagai karya untuk menunjukan kreatifitasnya dari berbagai bidang, seperti bakat menari, melukis, memasak dan lain sebagainya. Selain itu pada kondisi pandemi saat ini, aplikasi TikTok juga dapat meningkatkan suasana hati pengguna.

Dengan kondisi yang mengharuskan semua kegiata dilakukan dari rumah baik itu bekerja, belajar, dan lain sebagainya. Walaupun saat ini telah diberlakukan New Normal, rasa takut, khawatir, dan stres masih menyelimuti hati masyarakat melihat korban jiwa yang terus bertambah hingga saat ini (Yuwono, 2020: 136). Sudah pasti rasa takut menyebabkan masyarakat untuk tetap diam di rumah, dan saat sendiri seringkali muncul rasa bosan salah satu cara untuk membuat suasana hati menjadi lebih baik adalah dengan bermain TikTok baik itu hanya menonton karya orang lain ataupun membuat video sendir dan mengunggahnya ke media sosial. Bermain TikTok juga merupakan sarana untuk berolah raga. Gerakan yang dilakukan untuk membuat 
suatu video, merupakan bentuk olahraga yang asik dilakukan agar kita terhindar dari rasa malas untuk bergerak. Melihat hal ini, bagus untuk orang yang malas berolah raga, karena saat bermain TikTok tanpa kita sadari telah melakukan gerakan yang mampu membakar kalori dalam tubuh.

Pengaruh negatif dari aplikasi TikTok sebagai media penurun tingkat stres di era pandemi Covid-19 adalah, keinginan untuk membuat video yang berbeda dari yang lain membuat kreator tidak bisa membedakan mana aksi yang pantas dan tidak pantas untuk dipertontonkan. Banyak pengguna yang memang kreatif dalam membuat video agar bisa mendapat banyak respons dari orang lain. Tapi, mereka menjadi seperti tidak berfikir dahulu sebelum merekam apa yang mereka lakukan.

Mereka hanya memikirkan bagaimana cara membuat video yang bagus, menarik dan banyak respons dari penonton tanpa peduli dengan apa yang mereka tampilkan itu baik atau buruk untuk orang lain maupun dirinya sendiri. Hal inilah yang memicu aplikasi ini menjadi media Cyber Bullying karena video yang diunggah tidak layak untuk ditonton dan menjadi sasaran komentar para pengamat media sosial, dan akhirnya akan merugikan diri sendiri (Damayanti dan Gemiharto, 2019: 12). Aplikasi ini juga membuat para pengguna membuang-buang waktunya untuk membuat dan melihat video orang lain, sehingga kurang produktif dalam mengerjakan sesuatu yang lebih bermanfaat. Selain itu, karena pengguna lebih banyak dari remaja yang masih bersekolah, asik bermain TikTok membuat lupa waktu belajar dan mempengaruhi prestasi belajar siswa.

\section{SIMPULAN}

Di era pandemi Covid-19 saat ini mengakibatkan masyarakat merasa bosan dan stres karena belum terbiasa dengan kondisi yang saat ini tengah dialami. Dalam kondisi ini membuat masyarakat menggunakan berbagai alternatif untuk mengurangi rasa stres, salah satunya adalah aplikasi TikTok. TikTok merupakan media sosial dan platform video musik asal Tiongkok. Aplikasi ini dirilis perdana pada September 2016. Mulai populer di Indonesia pada tahun 2018. TikTok adalah sebuah aplikasi android yang memberikan special effects, unik, dan menarik yang dapat digunakan oleh pengguna dengan mudah sehingga membuat video pendek dengan hasil yang bagus serta dapat dipamerkan kepada pengguna lainnya. Sebanyak 64\% mengatakan bahwa TikTok adalah media penurun tingkat stres di era pandemi Covid19. Meski ramainya penggunaan aplikasi TikTok, TikTok bukan satu satunya alternatif yang digunakan masyarakat sebagai media penurun tingkat stres di era pandemi Covid19.

Dalam penggunaan aplikasi TikTok, sama halnya dengan media sosial yang lain yang menimbulkan berbagai pengaruh pada masyarakat baik positif contohnya seperti kita mampu mendapatkan berbagai informasi terbaru melalui aplikasi TikTok, berbagai video menarik, video lucu, video tutorial memasak dan lain sebagainya. Contoh pengaruh negatif dalam penggunaan aplikasi TikTok adalah masih adanya video yang tidak pantas untuk dipertontonkan, yang memicu adanya pembulian dan hal lain semacamnya yang tidak baik untuk diri sendiri maupun orang lain. Semua dampak yang diakibatkan tergantung dari bagaimana masyarakat menggunakan aplikasi TikTok. 


\section{DAFTAR PUSTAKA}

Kompas.com. (2020). WHO Tetapkan Wabah Virus Corona Sebagai Pandemi Global. [Online]. Available at: https://www.kompas.tv/article/70893 /who-tetapkan-wabah-virus-coronasebagai-pandemi-global [Diakses: 15 Desember 2020].

Aufar, A. F. (2020). Kegiatan Relaksasi sebagai Coping stress di Masa Pandemi Covid19. Jurnal Kolaborasi Resolusi Konflik, 2(2), 158.

Aufar, A. F. (2020). Kegiatan Relaksasi sebagai Coping stress di Masa Pandemi Covid19. Jurnal Kolaborasi Resolusi Konflik, 2(2), 158.

Tobing. S. (2020). Ekonomi di Tengah Pandemi, Apakah Akan Terjadi Lagi Depresi Besar [Online]. Available at: https://katadata.co.id/sortatobing/fin ansial/5e9a41c96a480/ekonomi-ditengah-pandemi-apakah-akan-terjadilagi-depresi-besar. [Diakses: 14 Januari 2021]

Muslim, M. (2020). Manajemen Stress pada Masa Pandemi Covid-19. Jurnal Manajemen Bisnis, 23(2), 192.

Muslim, M. (2020). Manajemen Stress pada Masa Pandemi Covid-19. Jurnal Manajemen Bisnis, 23(2), 192.

Kompas.com. (2020). Bagaimana Dampak Stres Pandemi Corona pada Kesehatan Mental dan Fisik. [Online]. Available at: https://health.kompas.com/read/202 0/05/10/190700368/bagaimanadampak-stres-pandemi-corona-padakesehatan-mental-dan-fisik- [Diakses: 15 Januari 2021].

Adawiyah, D. P. R. (2020). Pengaruh Penggunaan Aplikasi TikTok Terhadap Kepercayaan Diri Remaja di Kabupaten
Sampang. Jurnal Komunikasi, 14(2), 136.

Susilowati. (2018). Pemanfaatan Aplikasi TikTok sebagai Personal Branding di Instagram (Studi Deskriptif Kualitatif pada Akun @bowo_allpennlieble). Jurnal Komunikasi, 9(2), 177.

Aprilian, D. dkk. (2019). Hubungan Antara Penggunaan Aplikasi TikTok dengan Perilaku Narsisme pada Siswa Sekolah Menengah Pertama. Jurnal IImiah Bimbingan dan Konseling, 2(3), 221.

Hasiholan dkk. (2020). Pemanfaatan Media Sosial TikTok sebagai Media Kampanye Gerakan Cuci Tangan di Indonesia untuk Pencegahan Corona Covid-19. Jurnal IImu Komunikasi, 5(2), 75.

Yuwono, S. D. (2020). Profil Kondisi Stres di Masa Pandemi Covid-19 sebagai Dasar Intervensi dalam Praktek Mikrokonseling. Jurnal Bimbingan dan Konseling, 5(1), 136.

Damayanti, T. dan Gemiharto, I. (2019). Kajian Dampak Negatif Aplikasi Berbagi Video Bagi Anak-Anak di Bawah Umur di Indonesia. Jurnal Komunikasi, 10(1), 12. 